\title{
ETHNIC AND TRIBAL GROUPS, BORDERS AND FRONTIERS, RESOURCES AND GOODS. MAPS TO UNDERSTANDING AFGHANISTAN
}

\author{
by Valeria Piacentini Fiorani
}

1. Afghanistan: a Multi-Ethnic Tribal Area. Cultural-Political, Administrative and Economic Realities

"This nation consists of a mere collection of tribes, of unequal power and with different habits, which are held together, more or less closely, according to the personal character of the chief who roles them"

Sir Henry Rawlinson, 1875

Territory and peoples. So far, nothing has changed. However, what is Afghanistan? What does this place name mean? Afghanistan is "the territory (ostān) of the Afghans". But who are the Afghans? We find mention of the Afghans for the first time in a chronicle of the $11^{\text {th }}$ Century CE (al-Ta'rīkh al-Yamīnī by 'Utbī), that mentions a village on the northern hilly borders of Baluchistan, which was inhabited its course. The silk-route prevailed imposing its economic and mercantile dogmas, and the lands of present Afghanistan became a much coveted booty for the various empires of the time, that aimed at having full control on the strategic passes of this hostile territory, and, with them, full control also on the markets and the wealthy mercantile traffics (in goods and pilgrims) transiting the North-South and East-West (see Map 1).

Professor of History and Institutions of Islamic Countries rd. In the Catholic University of the Sacred Heart, Milan - Italy - Scientific Director of an Historical-Archaeological Research-Project in Sindh (Pakistan) within the Research Centre on the Southern System and the Enlarged Mediterranean (CrISSMA) in the Catholic University of the Sacred Heart. 
Afghanistan as an independent state came into being at the start of the $18^{\text {th }}$ Century. It was the time when Russia and Great Britain were beginning to confront each-other in Central Asia, at peace and at war ${ }^{1}$.

Landlocked, but in a crucial strategic position at the core of South-Central Asia, Afghanistan's territory has always been a positive mosaic of different peoples far from being culturally and ethnically homogeneous. Today, at the dawn of its reorganization as an independent "Emirate", little or nothing has changed. Undoubtedly, Afghanistan was and still is a tribal area, where intertwines a network of cultural and religious factors. A harsh territory, strictly conditioned and challenged by its steep rocky mountains, cut by few narrow passages, where an army can easily be ambushed and crushed; whether it subsists, it will not be able to find resources enough in water, food or other supplies to survive in hostile territory. Whereas instead of a great army, small groups of well-trained mountaineers should be dispatched, they would soon be spotted and, easily ambushed, none of them would be able to escape their sad destiny. All in all, the Afghans are the rulers of their mountains and the masters of an unwelcoming territory dotted by barren plains. Where the water flows, it can be-

1 On Afghanistan, its history, the Anglo-Russian rivalry in Central Asia and the closely intertwining "Persian Question", the political-historical events following the First and Second World Wars, the cold war and the impact of a harsh economic crisis on the Afghan crisis of the 70s of the previous century, the mediation and intervention of the Soviet Union, following guerrilla and events that brought to the collapse and disintegration of the Soviet Union, new endless feuds and internecine wars, the rise of the Islam factor and its impact on the regional system and global affairs up to the ISAF and NATO interventions...on all these crucial issues there is a rich literature printed and digital (exceptionally vast and no less varied in quality). The same can be stated when referring to the geomorphological and human environment of this hostile region and its reactions to any foreign intervention in its internal vicissitudes. Given the objective of this article, I will restrict myself to a few writings, either accounts and reports by British officers dispatched to explore these hostile and unfamiliar lands and their peoples, or studies by 'protagonists' of the time and scholars that have had direct contact with the Afghan territory. Both genres can be considered as primary sources and mirror a human and geomorphological environment that little has changed up today in its patterns of life and response to the outside world and 'its' models of life and 'democratic' patterns. Both genres provide precious "maps" to the understanding of Afghanistan and its systemic structures.

Here, I wish to express my sincere gratitude to Dr G. Sebastiano Scarcia, who has validly contributed to an analytical selection of the literary material that is at the basis of the following evaluations. 
come an enemy due to sudden rainfalls, snow-melting, and devastating floods; where the water disappears into the cracked soil, life disappears, too, and only a few bushes survive. Despite all, rivers are there, but liable to change their course and where the surrounding plains are not properly irrigated, soon they become barren lands. However, where human genius and skill have been able to manage their force and organize the territory, then wonderful oases blossom, cities and towns prosper with their wonderful monuments, testimony of their glory and a glorious past. There, merchants and traders of all ethnicities and religions converge, and markets are replenished with goods either produced in loco or there conveyed by caravans and convoys.

To the South-East of this harsh region, the impenetrable wall of the Himalayas still represents an impassable bastion against invasions and aggressions. To the South, the low slopes of Hindustan and the lower slopes of the dominant mountains gently striking east-west allow to connect through the Khaybar Pass the green fertile valleys of Jalalabad, today still seat and dominion of the legendary leader of the Ghilzay confederation and the Hezb-e Islami, Gulboddin Hekmatiyar, with the fertile lands of Peshawar and its beautiful historical town, present capital city of the Pakistani Province of the Khaybar Pakhtunkhwa. To the West, the Lorelay and Chagai Passes allow to connect the fertile regions of Kabul and Kandahar with northern Balochistan, Quetta and the Bolan Pass, the only practicable passage to South Balochistan, Makran and the harbour of Gwadar, presently one of the major issues at the core of the Indo-Pacific Us-Chinese confrontation. The Central Massive is at the crossroads of the EastWest/North-South routes and dominates them. Along the great EastWest road, prospered and still are very active markets the historic towns of Ghazni and, to the west, Farah and Herat, thresholds to the Iranian world. To the north, on the present frontier between Uzbekistan and Afghanistan, Termez (the ancient Tirmidh) stands on the Uzbek side, another historic town with its marginally desert land made economically productive through the application of traditional irrigation practices; opposite, in Afghanistan, stay Balkh and Mazare Sharif, this latter still headquarter of the powerful Uzbek warlord, Rashid Dastum. Nearby, in the strategic region of the Panjshir, thrive some villages inhabited by Tajik peoples, hint at the high level of 
agricultural prosperity, which reflects the success of contemporary irrigation and a skilled management of the territory blessed with much sought-after mineral resources (see Map 2 ).

This is the forbidding territory of the Afghans, who twice - challenged by the British great armies - had the upper hand on their forces... superb military expeditions ended up the first in a positive disaster where nearly nobody could escape death and tortures (1838-

2 The First Afghan War (1830-1842) witnessed a grey deft suffered by the British Indus Great Army, which was almost completely annihilated during the retreat from Kabul. The Second Afghan War (1878-1880) took place when the Russian-British rivalry was on the edge of a positive war due to British suspicions and over-sensitiveness, on the one hand, and essentially Pashtun un-loyalties, on the other. Persian archives and Russian documents do not confirm any Russian plan to outflank Inner Asia and invade India via Afghanistan. The 1878-1880 war came to an end with the battle of Kandahar and the Treaty of Gandamak, which signed a sort of temporary settlement of this strategic border. A Third Anglo-Afghan War took place at the start of the previous century, concluded with the Treaty of Rawalpindi in 1919, in which Great Britain recognised Afghanistan as an independent state, fixed the border along the so called Durand line, and the frontier was set at the Khaybar Pass, as it still stays. As said in the previous footnote, about the Anglo-Russian rivalry in Central Asia there is a vast literature and valuable articles based on the British Archives. With regard to 'events', see V. PiacentinI FIorani, La penetrazione russa in Asia Central 1800-1907, in "Storia e Politica", n. 4, 1966. pp. 598-628, and n.1, 1968 pp. 102-143. About the First Afghan War (1838-1842) see the study by R IANNAZZI, La questione di Herat e la prima guerra anglo-afgana (1838-1842), in "Nuova Rivista Storica", nn. 1-2, 1985, pp. 31-72 and herewith cited literature and primary sources. Evocative and no less significant are the reports by some protagonists of the events, like H. HAVELOCK, Narrative of the War in Afghanistan in 1838-39, 2 vols., London, Henry Colburn, 1940; A. BuRnes, Cabool: a Personal Narrative of a Journey to, and Residence in That City in the Years 1836, 7, and 8, Karachi, $2^{\text {nd }}$ ed. Indus Publications, 1986. On the Second Afghan War and the events that brought to the fights, see also H.W. BELlew, A General Report on the Yusufzais, Lahore, repr. Sang-e-Meel Publications from $1^{\text {st }}$ ed. 1864, 1994; H.W. BELLEW, Journal of a Political Mission to Afghanistan, in 1857, under Major (now Colonel) Lumsden, with an Account of the Country and People, Lahore, Orient Research Centre repr. from $1^{\text {st }}$ ed. 1862, 1872; H.W. BELLEW Afghanistan and the Afghans Being a Brief Review of the History of the Country and Account of its People to the Present Crisis and War with the Amir Sher Ali Khan, Lahore, Sang-e-Meel Publications repr. from the first ed. Lahore 1878, 1979; G.T. Vigne, A Personal Narrative of a Visit to Ghuzni, Kabul and Afghanistan and of a Residence at the Court of Dost Mohamed with Notices of Runjit Sing, Khiva, and the Russian Expedition, Lahore, Sang-e-Meel Publications repr. from the original ed., 1999; AA.VV., North-West Frontier Province, Lahore, repr. Sang-e-Meel Publications, 1991; see also Major M.H. AnJum, A Study of the Second Afghan War (1878-1880), 2 vols., Jhelum, Bhatti Publishers, 1979. No less significant are the narratives by contemporary officials between the 1772 to 1900 from Quetta's archives, collected by a local eminent historian 
1842), whilst the second (1878-1880) culminated in diplomatic and military skirmishes with the restless Pashtun Tribes, and resulted in a fragile agreement ${ }^{2}$. This is the territory of the Afghans who in the twentieth century, imposed a humiliating defeat to the no less superb Red Army. The same mountains and the same gorges that have sharply challenged with "bite and run" operations the formidable forces and the highly sophisticated technologies of the ISAF and NATO allied troops after $11^{\text {th }}$ September 2001.

Afghanistan: a hostile territory populated by different ethnos inherited from a past often very remote, each ethnos yet still organised in tribal groups, with their individual territory, traditions, language and history. People who came from different parts of Inner and Central Asia, from the Occident and the farthest Orient. There they arrived, either as people roaming from place to place in search of fresh pasture for their flocks, or as chased peoples in search of a sanctuary, or also as proud conquerors aiming at imposing their control on the region's tracks and strategic passes, and, with them, on the wealth there in transit. There, they settled, gave life to local potentates, and populated the lands that in the past their forefathers conquered and politically organised, social bodies that still have at the roots of their social-political organisation their specific cultural traditions (practises still orally preserved or norms handed over in written texts).

This is so far the political and social reality in Afghanistan, where the territory has always conditioned political and social systems and their structural organisation.

Herewith, I will limit myself to some analysis on the country's major groupings. The approach has been articulated through broad concepts, which are at the roots of both cultural-theoretical information and practical realities. These latter may represent as many precious clues to the understanding of present day experience (see previous footnote).

Ahmed Aziz Luni: A.A. Luni (ed.), The Afghans of the Passes, 2 vols, Quetta, Zeeshan Printing Press, 1994; A.A. LunI, Afghans of the Frontier Passes, Quetta, New Quetta Bookstall, 1992. See also J.w. SPAIN, The Pathan Borderland, Karachi, Indus Publications $2^{\text {nd }}$ ed., 1985; Brigadier FIDA HUSSAIN MALIK, Waziristan. The Simmering Backyard, Karachi, Shahab Publications, no date. Evocative testimony of the Brohui (Kurd) costumes and traditions is the narrative by D. Bray, The Life-History of a Brahui, Karachi, publ. Royal Book Company - repr. from the $1^{\text {st }}$ ed. 1913 Royal Asiatic Society, 1977. 
Table 1 - The main ethnic-groups area according to the official census held in 2019 is as follows ${ }^{3}$.

\begin{tabular}{llrlrll}
\hline Afghanistan & Pashtun & $42 \%$ & Sunni1 & $80 \%$ & Pashtu (uff) & $35 \%$ \\
38.041 .754 & Tajik & $27 \%$ & Sci'i $19 \%$ & Persian afghan (dari) & $50 \%$ \\
& Hazara & $9 \%$ & Others & $1 \%$ & Turkik Languages & \\
& Uzbek & $9 \%$ & & & (Uzbek, Turkmen) & $11 \%$ \\
& Aimak & $4 \%$ & & & Other minor languages & \\
& Turkmen & $3 \%$ & & & $(30$ languages c.) & $4 \%$ \\
& Baloch & $2 \%$ & & & & \\
& Others: & $4 \%$ & & & & \\
\hline
\end{tabular}

Pashtun (or Pathan). A wide tribal confederation (about 15 million in 2019), united by the common Pashtu language but deeply divided internally by chronic rivalries, for example between the Ghilzay/Ghalzay and the Durrani/'Abdali, the Durrani and the Ahmadzai, and so on. They are Sunni (officially Hanafite) and of Iranian stock. Excellent soldiers and mountaineers, were often engaged as mercenary troops.

Tajik. The Tajiks are also called Farsiban or Persian-speaker people. They speak a sort of 'Persian afghan' called Dari. This is about the second ethnic group numerically, and they 'were' mainly to be found around Herat, Farah and in regions to the northeast of Kabul and towards the border with present Tajikistan. Tajiks are of Iranian stock and therefore Sunni. However, according to recent indicators, amongst the Tajik peoples there is also a certain number of Shi 'i. Settled people. Since very ancient times they were usually engaged in trading activities and any kind of mercantile transactions (the word tajik comes from the Russian tačik $=$ merchant). Also employed as interpreters and bureaucrats, they furnished the administrative backbone of the Afghan political structures... and that of surrounding countries, too, in particular Uzbekistan (so far). After September 11, 2001 September, the Tajik component has largely been employed by ISAF and NATO contingents as interpreters and for other jobs within the "Western" apparatus.

Hazara. A people of 'Mongol' origin, gradually 'Iranicised' over the centuries as they moved from their original Altaic homes towards the Iranian world. The majority is Shi'i. Selected troops of the Genghiz Khan's

3 The figure given by this 'official' census is however quite tentative, due to uninterrupted migratory waves towards bordering and out-of-area countries, and to the fact that some major tribal groups are still nomadic, seasonally roaming in search of fresh pasture for their herds. 
army, they would be stationed by the Mongol chief in the rocky Central Massive of Afghanistan to guard and defend the strategic passes of the region whilst the Mongol leader moved eastwards and westwards at the world's conquest. Mountaineers and sturdy warriors, they were and still are excellent mercenary troops. They were recruited as selected corps in the Pakistani army, and distinguished themselves during the three Pakistan-India wars for Kashmir, which resulted in a smashing victory for Pakistan and a still unsolved question for the two countries and the international community. The Hazaras still form a special body in the Pakistani Army. They are also present in great numbers in northern Pakistani Balochistan, around Quetta, where they converged as special 'troops' and leading officials in service of the then Governor of the Balochi Province, Musà Khan, the charismatic Hazara general of the Kashmir wars. In both Afghanistan and Pakistan, they had begun to settle; educated, they still are a network of selected officers within the administrative apparatus.

Tribes of Uzbek Turkish stock. These are to be found to the north of the Hindu Kush, that is to say in the northernmost Afghan regions on the border with present Uzbekistan, especially in and around Mazar-e Sharif. Sunni. Their native language is Uzbek, a Turkish language.

\section{Tatars.}

Baloch. To be found along the Lorelay and Chagha'i Passes, and at Kandahar. They are considered the guardians of the western frontiers between present Pakistan and Afghanistan. Notable are the Marri and Bughti tribal groups.

Turkmen. They are to be found all along the borders with present Turkmenistan. Still largely nomadic. Sunni. Native language Turkmen, a Turkish language.

Chitralis and, further eastwards, Uighur, Pamiri and Kurd. Pamiris and Kurds are of Indo-Iranian/Indo-European stock, and their 'national' language is Brohui. No specific Islamic religion, but only political convenience. Still well alive traditional cults and black magic. The Uighurs' native language is Uighur (a Turkish language). They are from Central Asia, where they have traditionally inhabited a series of oases scattered across the Taklamakan Desert within the Tarim Basin. In the 12th Century, they gave life to a Christian reign ruled by a "Presbiter" called Gianni, renowned for his inflexibility and his persecutions on any other religious cult. The Uighur reign would be first defeated in the second half of the $12^{\text {th }}$ Century by Sanjar, a Seljuk leader, and his brother, both recorded in Euro- 
pean manuscripts as the "Saniarid" brothers; later, they would be crushed by the Mongol armies. Then, the Uighurs shifted towards the Chinese frontier, settled in Xinjiang (on the borders with present Kirgizstan and the Chinese Autonomous Province of Xinjiang). A Uighur group still lives in Afghanistan, in a mountainous region, which stretches to the northeast lik e a finger between the Pamir and the Jammu-and-Kashmir chains, and borders for a few kilometres with China, a strategic position that has always been rising Chinese suspicions and alarms for their trans-border activities. According to present figures, the Uighurs are mostly Muslim.

Overall, we are confronted with a positive mosaic of intertwining cultural and religious factors, that have chronically represented elements of regional instability. They are still there, with their diversities, traditional costumes and codes, with their everlasting enmities and family rivalries. Little or nothing has de facto changed. The protagonists of the events (or their immediate successors) that brought to a harsh confrontation with the Soviet Union and the disintegration of its Central-Asian 'empire' are still there, and very active in their own traditional territories (Summer 2021). Endless conflicts that during the last fifty years circa, notwithstanding generous efforts of the United Nations, have seriously endangered and yet still endanger the collective security in a region whose geo-strategic and geoeconomic relevance is well-known to the international community ${ }^{4}$.

\section{Political-Administrative Structures. Internal Mechanisms}

"Yesterday is History,Tomorrow is Mystery, Life is To Day" J. Ergas

The organisation of knowledge. Its impact on Power and Power's management structures. In many self-defined "Islamic" states, the cold war had set under way a process of internal dissolution, which

4 On Afghanistan in general (history, morphology, ethnic-tribal composition) there is a vast choice of literature. Still relevant for its 'information' is the study by L. DUPREE, Afghanistan, Princeton-New Jersey, Princeton University Press, 1980. On the ethnic composition, well-documented and still significant for the backstage and fieldwork of the authors, are: W. Fraser-TytLer, Afghanistan, London $3^{\text {rd }}$ edition, M. Gillett, 1967, and O. 
was reflected on the divarication of the so-called "memory of power". That is:

- on the one hand, it had put in motion a new process of the organisation of knowledge, and of the organisation of the society around such knowledge, on the basis of new conceptual categories and institutional models. In other words, what is commonly defined as the "process of modernisation";

- on the other hand, the roots remained deeply embedded in the oral tradition and the customs of the past ... even of a very remote past. In the first case, we saw the formation of a "modern and democratic" government élite, educated in line with avant-garde models, also referring to most sophisticated technologies. In the latter, there was the laborious process of preserving traditional knowledge, recording this and, alongside, the rediscovery of codes and institutions, which, in that remote past, had represented instruments indispensable for the wielding of power and that force always closely linked in power. Thus, two cultural heritages were moulded.

Afghanistan was not immune to this process, especially after the Soviet intervention. On the one hand, the Tajik people had technology and with it, the management of economic and administrative power. On the other, the Pashtu community held the force and, with it, its power. Though well perceiving the importance of looking ahead from the technological point of view, they remained tied to the values of oral tradition and strictly self-referential. This gave way to a "religious" process, where the Islam-factor had a central role, that of preserving traditional knowledge, recording this and, at the same time, rediscovering those institutions and "codes" which represented their indispensable instruments of power and its management. Prominent in this respect was, at that time,

ROY, L'Afghanistan. Islam et modernité politique, Paris, Coll. Esprit/Seuil, 1985; W. FrASER-TYTLER, Islam and Resistance in Afghanistan, Cambridge, Cambridge University Press, 1985; W. Fraser-Tytler, Géopolitique de l'Asie Centrale, in "Cahiers du Monde Russe et Sovietique", n. 1, 1991. A keen analysis of the regional and geopolitical situation in Central Asia following the "Soviet Afghan War" and its strategic implications is that by Naumkin; V. NaumKIn (ed.), State, Religion and Society in Central Asia - a Post-Soviet Critique, Reading, Ithaca Press, 1993. See also V. Piacentini Fiorani (ed.), La disintegrazione dell'impero sovietico. Problemi di sicurezza nazionale e collettiva in Asia Centrale, Roma 3 vols, Rivista Militare - Collana Ce.Mi.S.S., Sticca Mario di Giannini pub., 1995. V. PiacENTINI Fiorani, The Afghan Puzzle, in "The Iranian Journal of International Affairs", n.3, 1996, pp.653 - 672. See also above note (2). 
the role played by Peshawar University and its Institute of Islamic studies. Hazara groupings, who had begun to settle in towns, rapidly welcomed education and modern categories of formation, opening a third 'front' and a tough confrontation with the other two ethnic groups, Pashtun in particular. Given the environmental structure of the country, soon this process became relatively closed and self-referential, difficult to modify when it became an instrument of power and came to power after the end of the cold war and with the disintegration of the Soviet Union. It gave way, more or less gradually and more or less supported by regional and out-of-area actors, to new organised bodies (political parties and religious groupings), which soon gave life to a ferocious internecine war, that ended up with the victory of the leader of the Hezb-e Islami, charismatic guide of the Ghilzay Confederation, Gulboddin Hekmatiyar (Islamabad meetings, 1993-94). A focal 'summit' with Burhanoddin Rabbani, President of the Kabul Government and symbol of the Afghani political process of modernisation and technological education, sealed the allegiance (1996). It seemed that, at last, some sort of balance had been achieved. But it was not Afghanistan's destiny. In the disorder which had followed the disappearance of the clear guidelines of the cold war, the fragile "opposition forces" that had begun to organise themselves as legal forces within the new system, soon found themselves marginalised, whilst militant groups had the space and opportunity to reorganise their forces on the "outskirts" of the theatres of action. They exploited to the full the chances offered by the revolution in the field of computers and by the new technologies of globalisation, and gave birth to a new level of knowledge and power-management, characterised by trans-nationalism, trans-territoriality and trans-frontierism, and self-financing (illegal capital, drug-trafficking, criminality and so on). They had direct access to technological know-how, that, cunningly used, was calibrated and orchestrated so as to play on traditional Islamic consciousness. Against this backstage, the Qur'an Students and Warriors of God (the Taliban) made their appearance on the political scene and signed a new era of unrests and internecine wars... with new generous interventions from neighbouring and out-of-area protagonists... up to the 11 September ${ }^{5}$. Thence, the

5 It is here that the Salafiyya positively enters the picture, too, first as a purist Islamic movement, supported by Saudi Arabia and hosted by the King Feisal Mosque and its Centre for Islamic Studies in Islamabad. It represented the "moderate approach", and referred to 
intervention of new formidable actors and their military units (ISAF and NATO forces) which were stationed on Afghan territory claiming to bring, with a peace-process that might put an end to an endless conflict, also education, modernity, technology and economic welfare to the harshly proved Afghan people.

I will not deal with the historical details on how events developed (see also below §3). Be that as it may, on a more pragmatic ground little or nothing changed in Afghanistan. The Western intervention and "security", far from being a solution to endemic regional fights, accentuated the inter-ethnic/inter-tribal/inter-religious rivalries, which brought to a growing migration of refugees, renewed frictions all along the porous Afghan frontiers, a new wave of extremist propaganda and terroristic attacks by different Islamist groups.

However, a certain link continued to exist without interruption between the two levels of knowledge. The arrival and spread of new technologies and instruments of production inevitably led to some changes and to the creation of "institutional" centres, which aimed to enforce and accelerate the modernisation process through education. Yet, the reciprocal relationship between technological development and preservation of ancient knowledge never faltered or diminished; indeed it became even closer as the leaps forward of technological know-how led to increasingly marked transformations in life, daily habits and costumes in some specific ethnic groups and social classes. Once again, opposition forces that had begun to organise themselves as legal forces within the new system of the Kabul government and under the Western protection soon found themselves marginalised, whilst militant groups had the space and opportunity to reorganise themselves. They exploited to the full the chances offered by the revolution in the field of computers, electronic devices, globalisation and its new technologies, and gave

Mawdudi's doctrine and Qur'anic interpretation (tafsir), and this latter's school. It defiantly opposed the Deoband school and al-Qutbi's preaching. It is in this context that we may explain its strong hold first in the ideological-theological-cultural field and then in the ideology of action: Jihad bi'l-Sayffi sabil Allah only when other interventions (like negotiations, agreements, mutual respect and others) had failed. See V. PIACENTINI FIORANI, I Paesi del Golfo e l'Asia Centrale, in "Per Aspera ad Veritatem", Tipolitografia del RUD, Roma, 2001 pp. 509-532; V. Piacentini Fiorani, Il neo fondamentalismo. La dottrina del jihad fra opposizione e sostegno, in "Per Aspera ad Veritatem", 2003, pp. 121-156 - cfr. also www.sisde.it 
birth to a new level of military power. In other terms, on the one hand they exploited to the full their familiarity with the harsh Afghan territory, and, on the other, they structured their forces on trans-territorial operations of self-financing and on 'underground' agreements for the exploitation of the mineral resources, the new goods of which the Afghani soil is rich.

All in all, beyond the apparent madness of certain gestures, it is possible to perceive a lucid meeting of the traditional elements in their practical and more pragmatic application: new dynamics of militancy, a lucid fusion of new and traditional ideologies and knowledge, both sublimated into Islamic consciousness, which inevitably brought to renewed intensified inter-ethnic/inter-tribal rivalries and hatred. All of this reinforced by strong ambitions to obtain full power and control over the country and its resources 6 .

The elitist legacy of the technological knowledge, however, remained (Tajik and Hazara), and it is dramatically coming to the fore with the withdrawal of the Occident from the Afghan territory (Summer 2021) and the great void it has left behind.

Afghanistan's political structure. Democracy and democracies. Since the seventies of the previous century, which witnessed the Soviet intervention to restore order and democracy in Afghanistan (from 1979), events have followed in an internal and regional disorderly development with generous interventions by out-of-area actors. A state of affairs that, however, does not seem to largely differ from the preceding ages. In the accounts about the Afghan-British Wars of the nineteenth century (see above note 2), episodes of heroic resistance were

6 To pay the highest price were the Hazara, tough fighters and clever bureaucrats (see above). Soon, the Tajik had to confront themselves with a process of modernisation that in some cases disregarded the strict lecture of the norms of the Qur'an and the Sunna, often labelled by the Western thought as obsolete and to be reinterpreted at the light of new conceptions of social freedom and economic justice - a propaganda that found numerous adepts amongst the young generation. Conversely, the Pashtu peoples reorganised their files at the light of a strict Islamic vision and focused on the "Military" and the Islamic Thought. See V. PIACENTINI FIORANI, G. LIGIOS, Il Pensiero Militare nel Mondo Musulmano, Milano, vol. 16 Collana Ce.Mi.S.S., FrancoAngeli, 1996, new edition revised and updated: v. PIACENTINI FIORANI, G. LIGIOS, Islam. Logica della Fede e Logica della Conflittualità, Milano, FrancoAngeli, 2003. See also v. PIACENTINI FIORANI, Dopo l'11 settembre, in "Per Aspera ad Veritatem" - Rivista di Intelligence e di Cultura Professionale, 2001, pp. 809-826. 
certainly not lacking vis-à-vis British or Russian interferences, but we are mainly dealing with episodes that ended in precarious victories, followed by new divisions of the more or less rich spoils, soon followed in their turn by renewed ferocious bloody feuds, which often keep on such moments of heroism. All in all, beyond the names that designate and identify the individual institutions, the political-administrative structures of the Afghan system did not change until Summer 2021. What will be the follow up of this last moment of the Afghan history still pertains to "mystery", apart from the fact that Afghanistan is once again moving into one of those endemic phases of civil war and internal chaos... until a new charismatic personality won't rise to keep together the various parts, as Sir Rawlinson stated one and a half century ago.

Yet, through an analytical re-reading of the long chain of events as reported in the accounts of the officers and diplomats who lived them, it is possible to perceive how and which factors made them moving. It is also possible to evince the balances and un-balances between the individual ethnic and tribal groupings, how they played their games and which ambitions were set in motion beyond the official façade. In other words, it is possible to evince a "model" of the political Afghan system and its administrative structures and mechanisms, a kernel that, despite all, still survives, deeply rooted in a 'national' conscience.

A new glance to the geo-political and ethnic map of Afghanistan shows an un-homogeneous reality, where however tribal identity cannot either be touched or reformed or remodelled vis-à-vis the new impending times. Afghanistan's political system was and still is structured into a formal body where the various and heterogeneous tribal identities claim to be equally represented through free elections, giving life to a sort of balance between different cultures, powers and power-systems. Actually, this model and its "balance" have always been very theoretical. When they worked, they worked through a delicate distribution of powers and related benefits: military force and military supremacy were usually in the hands of the Pashtun peoples; the Tajiks represented the backbone of the bureaucratic and mercantile system. With the other groupings had been established understandings and matrimonial allegiances, which implied the sharing of influence and wealth. The balance could work and survive only when a strong charismatic leadership made it work. Yet, unbalances prevailed during the short history of this state, and gave place to uprisings, internal struggles and religious con- 
troversies, that did not fail to unbalance the routes' network vital to the economic welfare of the country and surrounding regions, too.

Despite all, the various ethnic groups have always claimed - and still claim - that this political system represents their identity and democracy.

The Afghan model of democracy. Which legacy, then, vis-à-vis the multifarious ethnic-tribal components of Afghanistan's social body? As said above, the major groups still do follow their own norms, oral and/or written, a patrimony handed over by the ancestors (real or mythical), untouchable however in its very essence, and in its social and political connotations. Not only. It is not even possible to speak about an ethnic homogeneity when referring to an ethnic-cultural group. Within each ethnic group, clash and revenges often break out due to conflicts on ethnic political identity. Each sub-grouping preserves its own story, customs and practices, which usually maintain the memory of everlasting "family" rivalries.

Yet, a kernel can be saved and a few common elements stand out, that have contributed to the forging of what has been proposed and counter posed to the Occident and "its" model of democracy as "the Afghan model of democracy"7.

Over the centuries and ranging from region to region, cultural context to another cultural context, it is possible to state that, in Afghanistan, the major element common to the majority of the social body is the concept of "state" and "statehood". Both speculation and doctrine usually anchor the concept of state/statehood upon two precise pillars: (I) the Leadership, that is the legitimate holder of the authority and its powers; and (II) the Military, that is the force vital to the effective exercise of all powers. These conceptions are depicted in all sorts of literature and pamphlets. These latter circulate, stir the mass, enter debates through both the ideological socio-political language and its considerations, and the military thought with its concepts and plans.

7 In our case, any realistic approach must bear in mind two dimensions, which always interact: the theoretical mechanisms, that can be identified with tribal codes and their forces, which are often set in motion by tradition and its emotional pathos, and the institutional and practical instruments through which they work or intertwine (not always, but sometimes also through the use of force, direct engagements and their logic, the Logic of Conflict). In the Peshawar University, there is a rich literature on this subject. No less active in $d a^{\prime} w a$, teaching and publications is the Centre for Islamic Studies c/o the Feisal Mosque in Islamabad. 


\subsection{The Leadership and its attributes: Authority and Power}

Authority is always human. It is in the hands of a person freely chosen by the tribal group among its own peoples. His authority is signed through a contract $\left(b a^{\prime} y a\right)$ between the community and whom it freely chooses to be its leader and representative. If the group is numerically small, the election is direct and takes place following the traditional habits. If the group is numerous, the election is indirect; each subgrouping elects its own representative, the representatives converge in a tribal assembly (Jirga), a selected body within the various social components of the group. The Jirga elects its own leader and the representatives to the Loya Jirga. This latter is a sort of "national" Parliament. The supreme Leader, Mir/Amir, until Summer 2021 identifiable with the "President" of the Government of Kabul, is chosen and designated by the Loya Jirga for his qualities, and is the representative of the social body of the whole country. Each group retains his own local leader, called mir (or shah or sardar), who has authority for ordinary business on the whole of his territory and his peoples.

It follows that Respect and Obedience go to the freely elected One. Respect and obedience last for the time of his life and, above all, as long as he keeps to the "pact". In other words, Obedience and Respect go to the Person and never to an Institutional structure. Both are lasting only for a short time. This reality marks the fragility of the institutional body and its system.

Power/Powers. Powers are in the hands of the authority, namely of the leader. As mentioned above, local leaders exercise specific powers on their own territory and for their peoples, especially when concerned with local traditional costumes and norms. The supreme Leader should exercise his power on the territory of the entire country, when it is required by the welfare of the social body. For example, he provides to exacting tributes for the country's development, like infrastructures, education, sanitary assistance, defence and so on. The authority (local and central) is also entitled by the contract signed with the community to use his powers to enforce the respect of the norms: traditional norms for the local leaders, national normative rules as voted by the Loya Jirga for the national territory. The authority also has the duty to defend the community when in danger (domestic feuds or external risks and 
menaces), and apply the norms fixed in the normative corpora (either oral or written) to enforce justice. The supreme Leader and his collaborators (present Ministers, that is the Cabinet or Supreme Coordination Council) - chosen by the Leader and validated by the Loya Jirga - are entitled to act according to their official position as executors of the Cabinet's decision once approved and voted by the Loya Jirga.

\subsection{Force and its use}

Force is in the hands of the authority. There is no authority without force. The authority is entitled to use force to impose order and to defend the community, provide security and impose order and respect of the practices and norms that run the community. In other terms, he is also the military leader (Chief of Army Staff, when the whole Afghani territory is concerned). And here, literature and debates enter a new field, that of Islam and its military thought; in other words, the Religious factor, its range of action, aims and objectives, tactics and strategies.

Inevitably, as already stated more than once, such a political-institutional architecture is characterised by recurrent unbalances, essentially due to the individual characters of the different tribal groupings inside their own ethnic group and outside it, often prevailing the single aspirations and 'economic' interests on the welfare of the whole community. Then, we have again a crisis; strife, feuds and internecine tribal wars create new chaos; new militant forces reorganise themselves aiming at conquering the supreme leadership of the state's social body... and so on. A recurrent pattern that, as stated more than once, has endlessly repeated itself in the course of the Afghans' life and history.

\section{Political Structures and the Religious Factor. Afghanistan: a National Theocratic State?}

Another reality has to be pointed out. Up to now, Afghanistan is an Islamic country. To run the life of the ethnic groups settled in Afghanistan, there is also the Islamic Factor.

The Islamic factor is a component that has always played a major 
role in Afghanistan, and it stood out especially when the country was thorn by internal feuds and/or external menaces.

Since four-five decades, the religious factor and its expression through a not at all new system - the Mujahedin-e Khalq, in a first moment, and the Taliban soon after - has been permeating the country and its social body. The latter are blamed for all the reversals suffered by the Soviet Union first and the West later (NATO forces and Western political international organisations are meant). They have also been blamed for the failure to build up a new and reunified Afghanistan through a military solution and the brilliant tactics of their militias. They have been censured for the violation of human rights and all humanitarian rules, harshly criticized for pillaging, raping, destructions and ravages of all kinds and nature. Yet, what is really Islam in Afghanistan?

To enter a detailed description of the multifaceted reality of Islam would mean to spend a whole life to study, investigate, analyse, evaluate... and then carry out fieldwork to verify, collect new data and evidence, region by region, tribal group by tribal group, sub-grouping by sub-grouping in a trans-border dimension, regional and global. And it would still not be enough.

Therefore, within the context of this concise presentation, the approach will be based on broad concepts, which are at the core of both doctrine (that is theoretical speculation) and reality. However, these models represent as many precious clues to the understanding of present day reality. When dealing with Afghanistan, we must never forget that the present has its roots in the past, a past that can also be very remote and represents a sort of local/regional reality, and, in any case, the cultural identity of a grouping.

In other words, a realistic approach to the theme must bear in mind two dimensions of the Islamic Factor, which always interact: the theoretical mechanisms (with can be identified with the logic of faith) and the institutional and practical instruments through which they work or intertwine (not always, but sometimes through the logic of conflict). In any case, in Afghanistan's Islam has always represented a force per se, acting through two basic pathways, both in line with regional traditions and practices. Two basic features and forces, as briefly shaped in the following lines.

a) In given contexts, Islam may constitute a force, which can organise informal and flexible structures, which, under certain circum- 
stances, are capable of developing an incredible force and a surprising balance of powers. These structures are based on religious ties and "loyalties". The loyalty of pupils to their teachers, especially in rural areas, or the loyalty of the 'ulema' for their schools, or spiritual ties like the religious fraternities (tariqa), or over again on common cults, wandering pir (holy men) and ghuru, and so on. These ties do not recognise territorial borders, geographical frontiers, institutional and administrative barriers. They also do not recognise ethnic diversities. They create a close-knit network of contacts, frequently underground, capable of surviving any official form of control and repression. This network acts and interacts with the de jure power (the administrative and bureaucratic bodies) on the one hand, and with the traditional political forces (often a much stronger, influential and authoritative de facto power). These religious ties are a form of group solidarity, horizontal/transversal, which can also unite other groups with common religious and social-political ideologies [Salafite movements, ISI and al-Qaida, for example].

b) However, behind these religious targets and their ideals, external aid and internal consensus have frequently created another, equally close-knit network of more material interests, often based on economic interests inevitably linked to a given territory. For instance: the control on specific resources that can be found on a given territory (like precious/semiprecious stones, coal, gas and oil, and copper, magnetite, uranium, rare earths and others to day: see Map 2) or herbs there cultivated and refined (like drugs), and their markets. A control that can take place through the collaboration of the "faithful" and their groups. Then, the religious factor gives life to another form of solidarity, a political solidarity based on the economic factor. Such solidarity can operate through the concession of "protections", which implies - where and whenever possible - jobs, positions, and a generous distribution of food, aid to the poor and needy, education and a no less generous distribution of copies of the Quran, cassettes, sacred texts, books and so on. Here, we are confronted with a tightly formed network of "worldly" earthly interests, which gives the "spiritual" and "religious" forces an unequivocal power. Against this earthly backstage, the religious actor often acts 
as ex post legitimising factor. This power, when it feels to be betrayed, is no less generous in retaliation, repression and revenges, where faith enters the service of another logic, that of conflict. In other words, it occupies (or re-occupies) a key dimension of its own, determining and legitimising ex post the play or interplay of politics and power, politics and pragmatic economic interests and their no less pragmatic management. This is the true power of such Islamic society. It exists more often "in fact" than "by right". And when it finds a charismatic guide, it can escape institutional control, can also cross internal borders and the frontiers recognised by surrounding states, it can also permeate the international society. Then, it becomes a formidable, political and military instrument when and wherever in the hands of a strong and charismatic leadership.

In the Afghani historical vicissitudes, the Islamic factor through these two religious currents always represented a prime actor. Just and to conclude a few hints8.

In March 1993, the Islamabad Agreement seemed to have crowned with Gulboddin Hekmatyar, then leader of the Hezb-e Islami and no less charismatic leader of the Ghilzay Confederation, the reunification of Afghanistan, a stabilised and independent Afghanistan. Gulboddin was the winner of a harsh and bloody war; the President of Afghanistan, Burhanoddin Rabbani and his Defence Minister, the Tajik Ahmad Mas'ud, were the losers, since their effective power and authority did not reach far beyond Kabul and its valley.

The various parts were still sitting around the peace-table when a new formidable actor entered the stage: the Taliban. In the name of Allah and the sacred text of the Qur'an, crying jihad bi'l sayf fi sabil Allah, they once again scattered the various pieces of a difficult puzzle and the region's equilibriums and security. Between the end of 1994 and 1995, Afghanistan was hit by another wave of violence. The other banner of the new warriors was the anti-drug war and the systematic destruction of the poppy fields in the Hilmand valleys and elsewhere. The desperate

8 V. Piacentini Fiorani, Analysis, Evaluation and Dialogue: Militancy and Cultural Islamic Order in Neo-Fundamentalist Movements, Crisis of Leadership and the Constructive of Education, in L. GERMANI, D.R. KAARTHIKEYAN (eds.), "Pathways out of Terrorism", UK - USA - India, New Dawn Press, 2005, pp.131-144. See also above notes (5) and (6). 
population fled from villages and towns, reduced to rubbles, and sought refuge in neighbouring areas that, in turn, were overcome by this new wave of desperate, disinherited refugees. But not only this.

At the start of the whole operation, the Taliban were mainly recruited from among the Durranis, whilst Hekmatyar and his Hezb-e Islami were from the Ghilzay. This inevitably opened a new internal conflict, an inter-tribal confrontation that ended up with the Durrani defeat and an open Pakistani intervention to lock and consolidate its frontiers. All around, the Hazara, the Tajiks of Mas 'ud (a charismatic warrior, also known as the "Lion of Panjshir", his territory) and the Uzbeks of Dastum, well established in precise territorial positions, contested the territorial primacy of the Ghilzays. The Hazara were the first to have a dramatic reverse in 1993, harshly betrayed by the Ghilzays, and then attacked in their same territory and massacred. ${ }^{9}$ At the same time, two crucial battles, respectively for Kabul and Herat, bottled up in difficulty Jalalabad and its Chief.

So far, we are still confronted with a mere interethnic war (Hazara, Tajik and Turks against a Pashtu primacy), on the one hand, and intertribal fights (Ghilzay vs. Durrani, within the Pashtu family), on the other. The religious factor was only an ex-post legitimising flag. Thus, disorder became the real ruler in Afghanistan.

At last, due to the intervention of other regional and not-regional actors, a truce was signed, a truce that, instead than putting together the various Afghani pieces, witnessed the intervention of new regional and out-of-area protagonists.

In 1996, the meeting of Gulboddin Hekmatyar with Burhanoddin Rabbani crowned Gulboddin as the armed arm of the Taliban movement, and sealed a (precarious) agreement with Rabbani, this latter a weak non charismatic political leader supported by the Occident and its regional allies, amongst these the Tajik Ahmad Shah Mas'ud. Be that as it may, this meeting signed the beginning of a new sharp internal conflict (the Hazara paid again a high price, this time with the Tajiks

9 Then, the Hazara began to migrate eastwards, setting up a stubborn military defence in the mountains surrounding Herat, whence they tried towere seek refuge (and jobs) in Iran. Numerous groups migrated to northern Balochistan, hosted there by the Hazara peoples of the late Governor of Balochistan, Musà Khan, and settled in refugee camps around Quetta. 
of Mas ' $u d$ ) and the rise to power in Afghanistan of a horizontal force loyal to Islamic judicial principles and the norms of its two major sources (the Quran and the Sunna).

This step took place after decades of internecine war, pillaging, famine, ethnic and inter-ethnic feuds, suffering and devastations. Osama bin Laden, an Arab who graduated from Oxford, cleverly gave to the movement a trans-ethnic ideal, based on common Islamic principles, which however respected the local ethnic and cultural identities with their traditional systems. Thence, the "education" of the Afghan people, and their training in the Quran, its norms and religious principles. Thus, he gave life to a new transversal structure founded on loyalties, solidarities and aid, which did not recognise either borders or cultural-ethnic identities (see just above). The force? This stood and still stands in the hands of the well-trained Pashtu majority.

All in all, during these last forty years we have been witnessing confrontation and clashes between the traditional local leaderships and their system of power and authority on the one hand, and new forms of political equilibriums introduced from outside into the traditional society of a country landlocked in its hostile environment since its remote Past. These new forms of government have not been able to dismantle neither the local traditional apparatus nor the Islamic factor. This latter is too deeply embedded in the humus of the local society and its tribal structures to be radically erased without creating sharp reactions and generational gaps.

After so many years and so many events, the Taliban movement once again comes out on top. It is again on the forefront of the Afghani stage under the banner of order and discipline (July-August 2021).

The Taliban are so far the guardians of frontiers, traditions and traditional codes. Their order are the Quran and its norms, and the Sunna of the Prophet Muhammad. They hold authority and power in the name of Islam. They are the force at the base of state and statehood. Top-policy makers, who really want the Taliban? Without any doubt, they still represent a current of Islamic radicalism not shared by other contending regional and out-of-area groups and protagonists. Without any doubt, their religious and political current has nothing to share either ideologically or de facto with the ISI terroristic extremist movement. Should they succeed in consolidating a re-unified Afghanistan within its an- 
cient political borders, they once again appear not to have neither sufficient administrative and diplomatic experience nor sufficient internal consensus to control the entire country, balance the heterogeneous ethnic-cultural Afghan milieu, manage its tribal territorial system, and reestablish discipline, security and order. Nor they seem to have any solid international consensus and support, at least for now.

Thence, since 1996, some yet still unsolved questions still stand: can we be confronted with a reunified Afghanistan? Or do we have to accept a great Pakhtunistan and its force in order to stabilise this territory so dear to the bordering and out of area actors? Or, paradoxically, a continuing state of crisis could help absorb forces in conflict and regional rivalries?

This is still the great dilemma for the local population....and for all the external actors. Markets are different, requested goods are no longer precious stones, slaves, silks, drugs...but new precious resources, much on request on the international markets for rapidly advancing technologies of both the Occident and the Orient. They are there, in the rocky mountains of Afghanistan and its hostile, unwelcoming territory.

Map. 1 - Physical Map of Afghanistan.

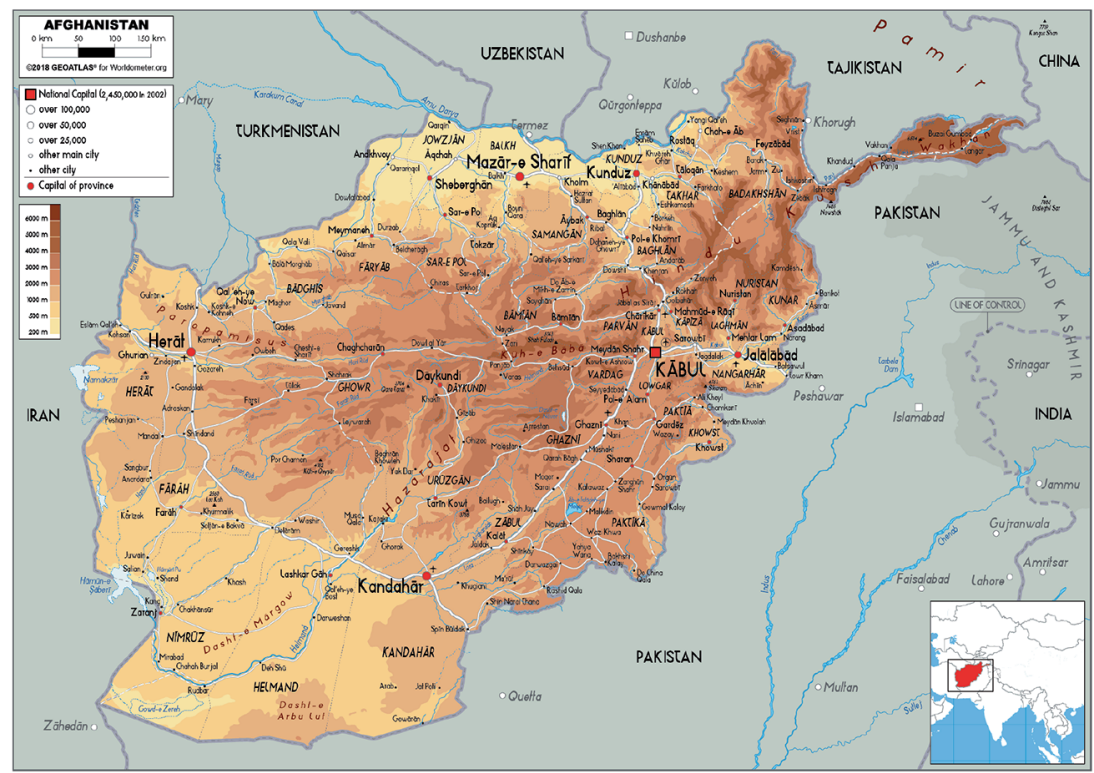


Map. 2 - Economic and natural resources ${ }^{10}$.

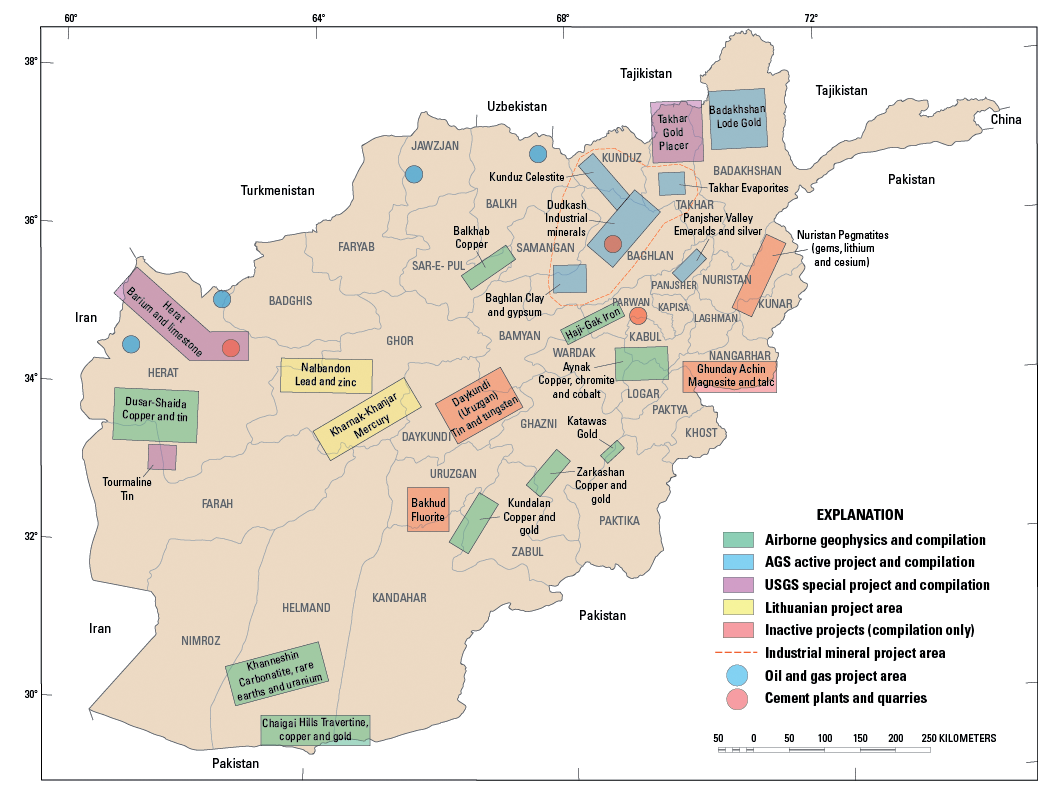

Riassunto - L'Afghanistan e le sue vicende sono tornati al centro dell'attenzione della comunità internazionale. Come stato indipendente, l'Afghanistan ha circa due secoli e mezzo di vita. Il saggio si sofferma su alcune realtà connaturate alla vita e alla storia del paese: si tratta di elementi 'strutturali', insiti sia nella sua configurazione geografica e geo-morfologica sia nell'animus delle genti che popolano il suo territorio inospitale, dominato da catene montuose, vere e proprie barriere che ostacolano i suoi contatti con i territori confinanti. Pochi e obbligati sono i passi, nessuno sbocco al mare, un microcosmo di genti di etnie fra loro molto diverse per tradizioni, cultura, religione, a loro volta lacerate al proprio interno da faide inter-tribali spesso radicate in lontane faide familiari. Preziose fonti di conoscenza sono sia quelle in lingua (orali e scritte) sia i rapporti di ufficiali e i resoconti di viaggiatori soprattutto inglesi del secolo XIX, sia gli scritti sovietici e russi degli anni '70-'90 del secolo scorso. Un'attenta rilettura di questi materiali letterari, filtrati attraverso una conoscenza diretta di alcune regioni, delle loro popolazioni e della relativa letteratura, consente di evidenziare dei fattori comuni, che si ripetono nel tempo e che da due secoli e mezzo - se non da prima - hanno rappresentato il perno intorno a cui si è costruita la storia afghana, con i suoi bilanciamenti fra poteri e forze diverse. Fattori comuni relativi ai temi 'stato/statualità' 'leadership, autorità e poteri' 'forza e suo uso'. Ne risulta un modello di statualità e delle sue strutture definito dai protagonisti locali come "Democrazia afghana", opposto e contrapposto alla "Democrazia occidentale".

10 Source: United States Geological Survey, 2009-2011. 